\title{
Properties of Adhesives Used for Connecting in Automotive Industry
}

Petr Valášek, Miroslav Müller

Faculty of Engineering, Czech University of Life Sciences Prague. Kamýcká 129, 165 21, Prague. Czech Republic. Email: valasekp@tf.czu.cz

An automotive industry belongs among the most important industrial branches in the Czech Republic as well as in the Europe. An adhesive bonding technology is a method of connecting which is used in many industrial branches nowadays. It also plays its irreplaceable part in area of a construction of automobile bodies. The adhesive bonding is the method which is easily implemented among requirements of a serial production. A strength and a reliability of adhesive bonded parts of automobile bodies and other traffic means are key. That is why adhesives used for the adhesive bonding in the automotive industry are characterized by their increased strength and resistance (e.g. adhesives Betamate). The paper describes the cohesive and strength characteristics of these adhesives. It focuses on a tensile strength, a hardness and a shear strength depending on a thickness of used sheets of metal when an increased thickness of the sheet of metal decreases its plastic deformation and so it decreases a liability of the adhesive bond to peeling.

Keywords: Bonding, Epoxy resin, Lap-shear strength

\section{Acknowlegement}

This paper has been done when solving the grant IGA TF (No.: 2014:31140/1312/3133).

\section{References}

[1] MÜLLER, M. (2013). Research of renovation possibility of machine tools damage by adhesive bonding technology. In: Manufacturing Technology, Vol. 13, No. 4, pp. 504 - 509.

[2] AL-SAMHAN, A., DARWISH, S.M.H. (2003). Strength prediction of weld-bonded joints. In: International Journal of Adhesion and Adhesives, Vol. 23, pp. 23 - 28.

[3] ABE, Y., et al. (2009). Joining of hot-dip coated steel sheets by mechanical clinching. In: International Journal Material Form, Vol. 2, pp. 291 - 294.

[4] VOTAVA, J. (2013). Influence of roughness of machined surface on adhesion of anticorrosion system. In: Acta Universitatis Agriculturae et Silviculturae Mendelianae Brunensis, Vol. 61, No. 6, pp. 1889 - 1896.

[5] MÜLLER, M., HERÁK, D. (2010). Dimensioning of the bonded lap joint. In: Research in Agricultural Engineering (Zemédělská technika), Vol. 56, No. 2, pp. 59 - 68.

[6] ADAMS, R.D., COMYN, J., WAKE, W.C. (1997). Structural adhesive joints in engineering. $2^{\text {nd }}$ ed. London: Chapman \& Hall

[7] MESSLER, R. W. (2004). Joining of materials and structures from pragmatic process to enabling technology. Burlington: Elsevier, 2004. 790 pp.

[8] BUCKLEY, J. D. (1986). Joining Technologies of the 1990s. Welding, Brazing, Soldering, Mechanical, Explosive, Solid-State, Adhesive. Park Ridge: Noyes Data Corporation, 480 pp.

[9] GRANT, L. D. R. et al. (2009). Experimental and numerical analysis of single-lap joints for the automotive industry. In: International Journal of Adhesion \& Adhesives, 2009, Vol. 29, No. 4, pp. 405 - 413.

[10]LANG, T.P., MALLICK, P.K. (1999). The effect of recessing on the stresses in adhesively bonded single-lap joints. In: International Journal of adhesion \& Adhesive, Vol. 19, No. 4, pp. 257 - 271.

[11]HABENICHT, G. (2002). Kleben: Gundlagen, Technologien, Anwendung. Berlin, Springer, 921 pp.

[12] NOVÁK, M. (2011). Surface duality hardened steels after grinding. In: Manufacturing technology, Vol. 11, pp. $55-59$.

[13] AFFATATO, S., RUGGIERO, A., et al. (2013). On the roughness measurement of the knee femoral components. In: BIOMODLORE 2013 Palanga (LT) 20-22 Sept. 2013 Vilnius Vilnius Gediminas Technical University Press Technica (Sauletekio al.11, LT-10223, Vilnius, Lithuania.), pp. 16 -18.

[14]CSN EN 1465. (1997). Adhesives - Determination of tensile lap-shear strength of rigid-to-rigid bonded assemblies. Czech Standards Institute. 
[15] VALÁŠEK, P., MÜLLER, M. (2012). Polymeric particle composites with filler saturated matrix. Manufacturing Technology, Vol. 12, Nr. 13, pp. $272-276$.

[16] MÜLLER, M., VALÁŠEK, P. (2013). Comparison of variables influence on adhesive bonds strength calculations. In: Manufacturing Technology, 2013, Vol. 13, No. 2, pp. 205 - 210.

[17] MÜLLER, M., HERÁK, D., VALÁŠEK, P. (2013). Degradation limits of bonding technology depemding on destinations Europe, Indonesia. In: Tehnicki Vjesnik-Technical Gazette, Vol. 20, No. 4, pp. 571 - 575.

[18] MÜLLER, M., CHOTĚBORSKÝ, R., KRMELA, J. (2007). Technological and constructional aspects affecting bonded joints. In: Research in Agricultural Engineering (Zemédělská technika), Vol. 53, No. 2, pp. 67 - 74.

[19]FESSEL, G. et al. (2007). Evaluation of different lap-shear joint geometries for automotive applications. In: International Journal of Adhesion \& Adhesives, Vol. 27, No. 7, pp. 574 - 583.

[20] YOU, M. et al. (2009). A numerical and experimental study of preformed angle in the lap zone on adhesively bonded steel single lap joint. In: International Journal of Adhesion \& Adhesives, Vol. 29, No. 3, pp. 280 - 285.

[21] AVILA, A. F., BUENO, P. O. (2004). Stress analysis on a wavy-lap bonded joint for composites. In: International Journal of Adhesion \& Adhesives, Vol. 24, No. 5, pp. 407 - 414.

[22] AVILA, A. F., BUENO, P. O. (2004). An experimental and numerical study on adhesive joints for composites. Composite structures, Vol. 64, No. 3 - 4, pp. 531 - 537.

[23] OLIA, M., ROSSETTOS, J. N. (1996). Analysis of adhesively bonded joints with gaps subjected to bending. In: International Journal of Solids and Structures, Vol. 33, No. 18, pp. 2681 - 2693.

[24] CAMPILHO, R.D.S.G., DOMINGUES, J.J.M.S. (2009). Numerical prediction on the tensile residual strength of repaired CFRP under different geometric changes. In: International Journal of Adhesion \& Adhesives, Vol. 29, No. 2, pp. $195-205$. 